\title{
PENDIDIKAN ISLAMI BAGI PENYANDANG AUTISME
}

\author{
Islamic Education for Authism
}

\author{
${ }^{1 * D w i}$ Sari Usop \& ${ }^{2}$ Lilik Kholisotin
}

\author{
${ }^{1}$ Primary School Teacher Study Program, Universitas Muhammadiyah Palangkaraya, RTA Milono St. Km.1,5 \\ Palangka Raya, Indonesia \\ ${ }^{2}$ Madrasah Ibtidaiyah Education Study Program, Universitas Muhammadiyah Palangkaraya, RTA Milono St. Km.1,5 \\ Palangka Raya, Indonesia \\ *e-mail : dsusop1st@gmail.com
}

\begin{abstract}
ABSTRAK
Pendidikan penting bagi manusia, termasuk penyandang autisme. Walaupun demikian, masih banyak penyandang autisme yang mengalami kesulitan dalam belajar. Salah satu kesulitan yang dialami ialah belajar tentang agama Islam. Tujuan penelitian ini : 1). Pentingnya Pendidikan Agama Islam bagi Penyandang Autisme di Kota Palangka Raya, 2). Model Pendidikan Agama Islam bagi Penyandang Autisme di Kota Palangka Raya. jenis penelitian yang digunakanadalahpenelitian kualitatif dengan menggunakan strategi naratif. Pengumpulan data dilakukan dengan wawancara serta dokumentasi. Subyek dalam penelitian, yaitu : 1). Guru, 2). Orang tua, 3). Tokoh agama, 4). Kementrian Agama Kota Palangka Raya. Teknik analisa data yang digunakan, yaitu deskriptif analitik. Hasil yang diperoleh dalam penelitian ini menekankan bahwa penyandang autis tetap wajib belajar agama, khususnya agama Islam. Hal ini tampak dari keikutsertaan penyandang autisme dalam pelajaran agama Islam di sekolah. Sedangkan di rumah, orang tua tetap mengajarkan anaknya agama. Pembelajaran agama Islam yang diberikan sangat variatif melalui proses bimbingan, penyamaan perlakuan dengan teman sebaya, peniruan perilaku teman sebaya, serta terapi murotal Al Qur'an.
\end{abstract}

Kata kunci: Pendidikan Agama Islam, Penyandang Autisme

\begin{abstract}
Education is important for humans, including people with autism. However, there are still many autistic people who have difficulty in learning. One of the difficulties experienced is learning about Islam. The purpose of this study: 1). The Importance of Islamic Education for People with Autism in Palangkaraya City, 2). Islamic Education Model for the Autism in the City of Palangkaraya. the type of research used is qualitative research using narrative strategy. The Data collection is done by interview and documentation. Subjects in the study, are: 1). Teacher, 2). Parents, 3). Religious figure, 4). Ministry of Religious Affairs of Palangka Raya City. The data analysis techniques used, was descriptive analytics. The results obtained in this study emphasize that autistic people are still obliged to study religion, especially Islam. This is evident from the participation of people with autism in Islamic studies in schools. While at home, parents still teach their children about religion. The learning of Islam given is very varied through the process of guidance, equalization of treatment with peers, imitation of peer behavior, and murotal therapy of the Qur'an.
\end{abstract}

Keywords: Islamic Education, People with the Authism

\section{PENDAHULUAN}

Jumlah penyandang autisme di dunia terus meningkat.Hal ini diungkapkan Kusumadayanti (2011), jumlah penyandang autisme sejak tahun 1987 adalah 1 anak per 5000 kelahiran. Terus meningkat selama 10 tahun, yakni: 1 anak per 500 kelahiran. Kemudian, tahun 2000 meningkat menjadi 1 anak per 250 kelahiran. Hal ini senada dengan insidensi anak autis yang disebutkan Santosa (2003), bahwa insidensi autisme di USA, Inggris, Timur Tengah, dan Asia mencakup 1: 250 anak. Secara perlahan, ilmu mengenai autisme dipelajari oleh masyarakat Indonesia.Istilah-istilah mengenai autisme di Indonesia sebagian besar merupakan istilah-istilah asing yang diterjemahkan ke dalam bahasa Indonesia. Hal ini terlihat dari 
materi-materi yang ada pada buku-buku, jurnaljurnal, film, e-book.

Semua materi yang dipelajari membentuk cara pandang baru bagi masyarakat Indonesia yang tertarik mengenai autisme dan penanganannya. Tidak hanya itu, pemahaman mengenai autisme mampu menumbuhkan kesadaran akan makna hidup sehingga mendorong adanya perubahan perilaku. Perubahan perilaku ini menuju pada satu titik, yakni suatu cara yang ditempuh dan mampu mengurangi bahkan menghilangkan gejala yang tampak pada penyandang autisme. Di Indonesia, secara perlahan bermunculan pusat-pusat terapi bagi penyandang autisme atau layanan tumbuh kembang anak. Hal ini disebabkan sudah banyak anak-anak yang mengalami autisme walaupun dalam jumlah yang kecil. Setiap kota di Indonesia memiliki kemungkinan beberapa penduduknya sebagai penyandang autisme, termasuk kota Palangka Raya. Berdasarkan hasil survey data yang telah dilakukan penyandang autisme bersekolah di SLBN 1 Palangka Raya dan SLBN 2 Palangka Raya.Selain itu, penyandang autisme di Palangka Raya juga tersebar pada beberapa sekolah di Palangka Raya serta penyandang autisme yang menempuh homeschooling.

Hasdianah (2013), mengemukakan ada tiga karakteristik yang menjadi khas penyandang autisme yaitu adanya hambatan atau gangguan dalam aspek: a). interaksi sosial, b). komunikasi dan bahasa, c). perilaku, di mana ketiga gangguan ini saluing berhubungan antara satu dengan lainnya.Secara psikologis, penanganan untuk penyandang autisme bertujuan untuk mengurangi atau menghilangkan hambatan yang dialami. Penanganan tersebut antara lain: adanya program pembelajaran, penerapan model, strategi, metode, maupun teknik pembelajaran dan terapi. Beberapa diantaranya: a). program komunikasi pra akademik (Koswara, 2013) yang bertujuan unttuk mengembangkan kemampuan komunikasi pra akademik anak autisme sebelum masuk pada pembelajaran akademik, b). penerapan terapi bermain yang bertujuan agar anak autisme mampu menjalin interaksi dengan orang lain, komunikasi, mengurus diri sendiri, mengendalikan agresivitas, mengurangi perilaku stereotip (Hasdianah, 2013), c). terapi perilaku dengan menggunakan metode analisis perilaku terapan untuk mengubah perilaku anak (Runtukahu, 2013).

Ditinjau berdasarkan Konsep Islam, pendidikan anak dimulai dengan memilih pasangan suami atau istri yang shaleh/shalihah. Hal ini seseuai dengan pernyataan Maghribi (2004) bahwa seorang laki-laki atau wanita yang ingin menikah, sebaiknya mencari pasangan yang shalih atau shalihah. Salah satunya adalah memilih istri yang shalihah. Maghribi (2004), juga menyebutkan beberapa kriteria pendidik yang teladan, yaitu: a). pemaaf dan tenang, b). lemah lembut dan menjauhi sifat kasar dalam bermuamalah, c). berhati penyayang, d). Bertakwa, e). selalu berdoa untuk anak, f). Lemah lembut dalam bermualah dengan anak, g). menjauhi sikap marah, h). bersikap adil dan tidak pilih kasih. Adapun hal-hal yang dapat diajarkan orang tua kepada anak mengenai pendidikan yang sesuai dengan kaidahkaidah Islam, yaitu: a). pembinaan aqidah, b). pembinaan ibadah, c). pembinaan kemasyarakatan, d). pembinaan jiwa anak, e). pembinaan fisik anak, f). pembentukan intelektualitas anak, g). bangunan kesehatan, h). meluruskan dorongan seksual anak (Suwaid, 2010). 


\section{METODOLOGI}

Penelitian ini adalah penelitian kualitatif dengan menggunakan strategi naratif. Wawancara dan dokumentasi adalah teknik pengumpulan data yang digunakan. Adapun subyek atau partisipan dalam penelitian ini adalah guru-guru, orang tua, tokoh agama, serta Kementrian Agama Kota Palangka Raya. Sedangkan teknik analisa data yang digunakan teknik deskriptif analitik.

\section{HASIL DAN PEMBAHASAN}

\section{Pendidikan Agama Islam yang diberikan Guru} di Sekolah

Ada 9 (sembilan) sekolah yang menjadi lokasi penelitian, yaitu : 1). SLBN 1 Palangka Raya, 2). SLBN 2 Palangka Raya, 3). TK AI Qonita, 4). SD IT Al Qonita, 5). SDN 5 Menteng, 6). SD IT Al Ghazali, 7). SDN 4 Langkai, 8). SDN 11 Langkai, 9).SMP Nurul Ihsan.

1. SLBN 1 Palangka Raya

Peserta didik yang bersekolah di SLBN 1 Palangka Raya terdiri atas berbagai jenjang dari taman kanak-kanak sampai sekolah menengah atas dengan berbagai ragam kebutuhan khusus yang dimiliki. Jenis-jenis kebutuhan khusus yang dialami peserta didik adalah kebutuhan khusus yang berhubungan dengan penglihatan, pendengaran, mental, gerak, maupun campuran dari beberapa jenis kebutuhan khusus.

Berdasarkan data peserta didik autisme yang diperoleh, ada 19 peserta didik yang bersekolah pada jenjang sekolah dasar yang terdiri atas : 17 l;aki-laki dan 2 perempuan. Pada jenjang sekolah menengah pertama ada 6 (enam) orang peserta didik dan semuanya berjenis kelamin laki-laki.Sedangkan di jenjang sekolah menengah atas ada 4 (empat) orang peserta didik dan berjenis kelamin laki-laki.

Proses belajar mengajar peserta didik autisme di SLBN 1 Palangka Raya dilakukan dengan jumlah peserta didik dibatasi tidak sampai 10 orang di dalam kelas. Sistem pembelajaran yang digunakan adalah sistem pembelajaran individu, di mana pembelajaran dilangsungkan dengan cara bergilir. Pembelajaran yang paling utama diberikan adalah pembelajaran tentang kemandirian melalui proses pembiasaan. Proses pembelajaran diawali dengan peserta didik dibiasakan untuk dapat duduk tenang terlebih dahulu. Setelah itu, guru baru dapat masuk ke pelajaran.

Pelajaran-pelajaran yang diajarkan sama dengan pelajaran-pelajaran yang dipelajari peserta didik-peserta didik di sekolah pada umumnya. Termasuk pelajaran agama Islam.Peserta didik dibimbing secara perlahan.Misalnya saat peserta didik dipeerkenalkan dan diajak untuk menghafal Asmaul Husna. Walaupun demikian, kemampuan menghafal Asmaul Husna tersebut juga dipengaruhi oleh tingkat kecerdasan peserta didik itu sendiri. Hal ini disebutkan oleh salah satu guru agama Islam di SLBN 1 Palangkaraya.Beliau menyebutkan bahwa peserta didik autisme yang memiliki tingkat kecerdasan normal mampu menghafal lebih cepat dari teman-temannya.

Demikian halnya dengan pembelajaran kemandirian, dilakukan secara perlahan dan bertahap.Melalui pembelajaran kemandirian ini, peserta didik juga diajarkan tentang kedisiplinan.Salah satunya dengan 
membiasakan peserta didik meletakkan sepatu di rak sepatu sebelum masuk ruangan kelas.Peserta didik juga diajarkan untuk menjaga kebersihan setelah buang air.

\section{SLBN 2 Palangka Raya}

Berdasarkan data dari SLBN 2 Palangka Raya, peserta didik pada jenjang sekolahdasar berjumlah 45 orang. Peserta didik yang mengalami autisme berjumlah 4 (empat) orang. Empat peserta didik ini terdiri atas 3 (tiga) peserta didik berjenis kelamin laki-laki dan 1 (satu) peserta didik perempuan.Sedangkan pada tingkat SMP dan SMA tidak ada peserta didik yang mengalami autisme.

Proses belajar mengajar peserta didik autisme dilakukan secara klasikal. Peneliti diijinkan untuk melihat proses pembelajaran serta berinteraksi dengan peserta didik autisme pada tingkat sekolah dasar. Ada dua peserta didik yang mengalami autisme. Guru menjelaskan materi secara klasikal. Peserta didik diajak untuk mendengarkan penjelasan guru tentang materi secara singkat.Setelah itu, peserta didik diminta untuk mengisi jawaban soal yang dituliskan di papan tulis.

Menurut guru kelas, pembelajaran utama yang diberikan pada peserta didik autisme adalah mengajarkan "kepatuhan". Hal ini disebabkan peserta didik senang melakukan hal sesuka hatinya.Misalnya, peserta didik dengan inisial T. Sangat aktif dan Senang berpura-pura akan membuang buku-buku atau benda ke luar jendela seraya ,memanggil guru atau berlari ke luar kelas. Saat mengerjakan tugas di papan tulis, $T$ tampak antusias. Walau demikian, $T$ senang menghapus tulisan teman-temannya yang sudah lebih dulu menulisnya di papan
tulis.Seluruh perilaku ini bertujuan untuk mendapatkan perhatian dari guru.

Adapun peserta didik dengan inisial $S$ lebih senang mengerjakan tugas dihadapan guru.S tipe anak yang pendiam.S memerlukan bimbingan dari guru dalam menulis, sebab tulisannya masih sering tidak sesuai garis, apalagi bila tidak dibimbing atau diarahkan.Bila diarahkan, $\mathrm{S}$ mampu menulis sesuai garis yang ada di buku tulis.

Berkaitan dengan pembelajaran agama islam, guru memberikan pengajaran sesuai dengan materi dan kebutuhan peserta didik. Selain itu, seluruh peserta didik diajarkan dan dibimbing untuk dapat berinteraksi dan berkomunikasi dengan orang lain. Salah satunya dibimbing untuk menyapa dan bersalaman dengan orang lain yang bertamu di sekolah. Peserta didik dibiasakan untuk mengucapkan salam dan bersalaman dengan guru saat pagi hari dan siang hari ketika akan pulang ke rumah dari sekolah. Dengan demikian, peserta didik menjadi terbiasa melakukannya dan menjadi responsif bila ada orang yang berkunjung ke SLBN 2 Palangka Raya.

3. SDN 4 Langkai Palangka Raya, SDN 5 Menteng Palangka Raya, SDN 11 Langkai Palangka Raya, SD IT Al Ghazali Palangka Raya, SD IT AI Qonita, TK Islam AI Qonita, dan SMP Nurul Ihsan Palangka Raya

Ketujuh sekolah ini memiliki kesamaan di dalam mmperlakukan peserta didiknya. Kesamaan tersebut terletak pada guru memperlakukan seluruh peserta didik sama, walaupun ada peserta didik yang mengalami autisme atau kebutuhan khusus lainnya. Seluruh peserta didik belajar di tempat yang sama sesuia 
dengan kelasnya masing-masing dengan sarana dan prasarana yang sama, seperti meja, kursi, dan perlengkapan sekolah lainnya. Pada saat proses pembelajaran, guru juga menyampaikan materi kepada seluruh peserta didik. Peserta didik yang mengalami autisme juga turut memperhatikan dan mendengarkan penjelasan guru. Saat guru memberikan tugas, peserta didik yang mengalami autisme juga diwajibkan untuk mengerjakan tugas tersebut.

Dalam masa mengerjakan tugas ini, guru berkeliling untuk memantau peserta diidk mengerjakan tugas. Termasuk memantau dan membimbing peserta diidk yang mengalami autisme dalam proses memahami pelajaran.

Untuk mempermudah proses pembelajaran, guru-guru di TK Islam Al Qonita memberikan pengarahan kepada orang tua maupun peserta didik lainnya mengenai kondisi yang dialami oleh penyandang autisme. Melalui pemahaman dan penerimaan yang telah diperoleh, guruguru sering meminta bantuan dari peserta didik lain untuk membantu dan memberikan arahan serta bimbingan kepada penyandang autisme. Hal ini cukup efektif dirasakan oleh guru. Peserta didik autisme autisme mau menuruti serta meniru tindakan teman-temannya. Demikian juga di SD IT AI Qonita, penyandang autisme mau mengikuti seluruh kegiatan keagamaan di sekolah. Pada awalnya tidak mau mengikuti. Setelah guru-guru memberikan bimbingan dan peserta didik autisme tersebut memperhatikan teman-temannya yang mengerjakan sholat saat telah tiba waktunya, secara perlahan mereka meniru perilaku teman-temannya untuk sholat atau mengerjakan hal lainnya. Akhirnya, peserta diidk autisme tersebut mau mengerjakan sholat. Seiring berjalannya waktu, peserta didik inilah yang selalu bersegera untuk pergi ke masjib saat waktu sholat telah tiba.

Selain itu, di SD IT AI Qonita dan TK Islam AI Qonita juga diperdengarkan murotal Al Qur'an dengan tujuan membiasakan peserta didik untuk mendengarkan lantunan Al Qur'an sejak dini. Selain itu, melalui memperdengarkan murotal Al Qur'an ini mmampu menimbulkan efek tenang dalam diri peserta didik, khususnya peserta didik yang mengalami autisme.

\section{Pendidikan Agama Islam yang diberikan Orang Tua}

1. Orang tua $F$ $\mathrm{F}$ adalah salah satu peserta didik di SDN 11 Langkai kelas III yang mengalami autisme. Peneliti diijinkan untuk mewawancarai ibunya F. Ibunya F menyatakan bahwa Fdiketahui autis ketika setelah usia 2 tahun, dirasakan perkembangannya terlambat dan termasuk anak yang hiperaktif. Oleh karena itu, orang tua $F$ memeriksakan kondisi Fadli ke dokter.Hasilnya $F$ divonis mengalami autisme.Kemudian, orang tua $F$ mulai mempelajari autis dengan mempelajarinya sendiri dan dari terapis atau dokter.

Dalam segi kemampuan akademik, $F$ tampak kurang menguasai serta masih belum mampu menguasai pelajaran di sekolah dengan baik. Misalnya, pada pembelajaran matematika sederhana, $F$ belum menguasainya. Penjumlahan, pengurangan, perkalian, pembagian sederhana.

F mampu mengurus dirinya sendiri, seperti makan, minum, berpakaian, mandi, buang 
air.Dalam pendidikan agama, orang tua $\mathrm{F}$ secara perlahan-lahan membimbing Funtuk mengerjakan sholat, berpuasa, menghafal Asmaul Husna. Selain dibimbing oleh orang tuanya, $\mathrm{F}$ belajar semuanya dengan cara meniru apa yang dilakukan orang tuanya, serta mendengar. $F$ mampu menghafal Asmaul Husna melalui media audio. Menurut ibunda, $F$ lebih cepat memahami dengan cara mendengar hal-hal yang disampaikan kepadanya.

Dalam membimbing, orang tua $F$ melakukannya dengan penuh ketegasan serta konsisten. Hal ini dilakukan, sebab bila tidak tegas, maka $\mathrm{F}$ tidak mau mendengar apa yang dikatakan orang tuanya. Sampai saat ini, Fadli sudah terbiasa untuk sholat dan berpuasa.F sudah mulai berpuasa sejak kelas 1sekolah dasar.Bahkan, saat menginjak kelas 3 ini, saat waktu berbuka puasa telah tiba, $F$ tidak mau berbuka.

\section{Orang tua Ay}

Peneliti bertemu dengan salah satu orang tua peserta didik dari SLBN 1 Palangka Raya berinisial Ay.Saat ini, usianya telah menginjak 20 tahun.Usia yang sudah memasuki usia dewasa muda. Menurut ibunya, Ay kecil merupakan anak yang hiperaktif.Aydiketahui mengalami autis ketika berumur 6 (enam) tahun.lbunya mengetahuinya melalui televisi. Hal ini dikarenakan selain hiperaktif, Ay mengalami keterlambatan dalam berbicara. Kondisi ini dipahami orang tua Ay sebagai suatu kewajaran. Sebab, dahulu ayah Ay pun mengalami keterlambatan bicara saat masih kecil. Selain mengalami keterlambatan bicara, Ay juga tidak mau bergaul dengan orang lain.
Kemudian, saat umurnya sudah cukup untuk sekolah, Ay bersekolah di TK tempat ibu Ay mengajar. Ay diajarkan berbagai macam hal seperti Asmaul Husna.Setelah ibu Ay mengetahui dari televisi bahwa anaknya mengalami autisme, untuk membimbingnya, Ay di sekolahkan di sekolah khusus, yakni di TK Al Qonita.

Saat ini, Ay telah berusia 20 tahun dan terdaftar sebagai peserta didik dengan jenjang pendidikan Sekolah Menengah Atas di SLBN 1 Palangka Raya.Hiperaktif Ay hilang saat sudah Sekolah Menengah Pertama. Berganti dengan menjadi pendiam.Selain itu, juga Ay suka berbicara sendiri.Bahasa yang digunakan pun kurang familiar. Secara umum, Ay sudah paham tentang belanja atau jajan.Kalau Ay ingin jajan dan minta uang pada ibu, la tidak mengatakan pada ibunya "ma, minta uang!".kalimat-kalimat yang diungkapkan Ay berupa kalimat pertanyaan :"ma, kurangkah duit ?".

Berkaitan dengan makanan, Ay sangat senang dengan nasi goreng. Bila ada nasi goreng, maka Ay bisa makan sendiri. Porsinya juga pas1 porsi atau 1 piring. Sedangkan kalau makan nasi putih harus disuapi. Sebab, Ay tidak suka makan nasi putih. Bila makan nasi putih, hanya sekitar 3-5 kali suap. la menyatakan "sudah kenyang". Setelah itu tidak mau lagi. Kalau dipaksa, Ay memilih untuk meninggalkan orang yang menyuapinya.

Sampai saat ini, Ay masih mengalami kesulitan di dalam menutup auratnya saat mau mandi. Ay dengan nyamannya menanggalkan pakaian tanpa rasa malu. Sang ibu mengaku bahwa hal ini merupakan suatu kesulitan yang masih 
belum ditemukan jalan keluarnya.Berkaitan dengan kebersihan, Ay sudah mampu mengurus dirinya sendiri, seperti mandi, berpakaian, membersihkan diri setelah buang air. Ay juga mampu sholat, namun belum dapat dibiarkan sholat sendirian. Ay masih suka tolehtoleh saat sholat. Dalam keseharian, orang tua Ay secara perlahan membimbing Ay sehingga memahami hal-hal yang baik dan buruk. Kakakkakak Ay juga turut memberikan bimbingan.

\section{Pendidikan Agama Islam bagi Penyandang Autisme menurut Tokoh Agama}

Satu tokoh agama yang berhasil ditemui oleh peneliti, yakni berinisial Z. Z mengungkapkan bahwa setiap anak memerlukan pendidikan agama yang diberikan oleh orang tuanya. $Z$ juga mengungkapkan bahwa ada 4 (empat) hal yang orang tua harus ajarkan pada anak, yaitu aqidah, ibadah, akhlak, dan dakwah. Keempat hal ini wajib diajarkan pada anaknya disertai do'a agar sang anak menjadi anak yang sholeh.

\section{Pendidikan Agama Islam bagi Penyandang Autisme menurut Kementrian Agama Kota Palangka Raya}

Untuk memperoleh data yang lebih akurat mengenai penanganan penyandang autisme, peneliti berkunjung ke Kementrian Agama Kota Palangka Raya. dengan tujuan untuk mengetahui apakah Kemenag Kota Palangka Raya memiliki program-program yang berkaitan dengan anakanak berkebutuhan khusus termasuk autis. Menurut ibu SM, pendidikan anak dimulai melalui pendidikan prenatal, yakni pendidikan sebelum lahir.Janin yang ada di dalam rahim ibu, dibacakan ayat-ayat suci Al Qur'an. Selain itu, pada malam jum'at, sang ibu mengambil segelas air dan meminta tolong suaminya untuk membacakan surat Yasin. Lalu, meminumnya. Hal ini diyakini ibu sebagai ikhtiar kepada Allah SWT agar janin yang dikandungnya nanti terlahir sebagai anak yang sehat walaupun usianya telah memasuki usia 42 tahun. Ibu sangat meyakini bahwa Allah SWT akan memberikan yang terbaik atas usaha yang telah dilakukannya tersebut.

Berkaitan dengan program dari Kementrian Agama Kota Palangkaraya tentang pendidikan anak-anak berkebutuhan khusus, di Kementrian Agama Kota Palangkarayabelum memiliki program tersebut. Disampaikan mereka baru memiliki satu Madrasah Ibtidaiyah Inklusi dan tidak ada peserta didik yang menyandang autis yang ada hanyalah anak hiperaktif. Walaupun demikian, Kementrian Agama Kota Palangkaraya turut andil dalam pemberian motivasi kepada orang tua dari anak-anak berkebutuhan khusus yang diselenggarakan oleh Dinas Sosial.

\section{Pentingnya Pendidikan Agama Islam bagi Penyandang Autisme di Kota Palangka Raya}

1. Orang Tua

Orang tua merupakan salah satu orang terpenting di dalam memberikan pendidikan bagi anak. Apapun kondisi anak tersebut. Termasuk pada orang tua yang memiliki anak autisme. Ini terbukti dengan orang tua dengan giat mengajarkan anak pendidikan agama. Mereka berharap anaknya dapat memahami dan mengamalkan agamanya secara baik. Hal ini terbukti dengan secara terus-menerus para orang tua dari anak penyandang autisme membimbing anaknya untuk sholat, mengaji, puasa, dan ibadah-ibadah lainnya. 
2. Guru atau pihak sekolah

Secara umum, pendidikan agama sangat penting diberikan kepada seluruh umat manusia di dunia ini. Tak terkecuali pendidikan agama Islam. Di Palangka Raya, seluruh sekolah memasukkan pendidikan agama ke dalam kurikulum pembelajaran. Setiap peserta didik berhak mendapatkan pendidikan agama sesuai dengan agama yang dianutnya. Demikian pula bagi peserta didik yang menyandang autisme.

3. Masyarakat

Elemen masyarakat yang dimaksud di sini adalah orang-orang di lingkungan sekitar anak penyandang autisme, tokoh agama, maupun dinas-dinas yang terkait dengan pendidikan anak.

\section{a. Teman sebaya}

Teman sebaya merupakan bagian yang sangat penting di dalam kehidupan sosial penyandang autisme.Melalui berteman, penyandang autisme belajar bersosialisasi dan belajar berbagai hal.Termasuk belajar agama.Mereka turut mendukung di dalam kemajuan perkembangan anak autisme. Hal ini tampak dari penerimaan mereka terhadap temannya yang mengalami autisme.Tentu saja penerimaan ini juga tidak terlepas dari peran guru di dalam memberikan bimbingan berupa penjelasan kepada para peserta didik mengenai kondisi teman mereka yang mengalami autisme. Melalui bimbingan tersebut, para peserta didik menjadi tidak canggung lagi menghadapi tingkah polah temannya yang mengalami autisme. Bahkan mereka dengan senang hati bersahabat dan membantu penyandang autisme di dalam proses pembelajaran. Peserta didik dengan senang hati menggandeng penyandang autisme ke mana pun mereka pergi di dalam setiap kegiatan yang dilakukan. Hasilnya, penyandang autisme merasa senang dan terjadi proses peniruan perilaku dari peserta didik yang mengalami autisme terhadap halhal yang dilakukan peserta didik lainnya yang bukan autisme.

b. Tokoh agama

Bagi tokoh agama Islam, pendidikan agama Islam sangat penting diberikan kepada anak, termasuk anak penyandang autisme. Walaupun dipandang dari sudut pandang hukum Islam, anak penyandang autisme tidak dikenai hukum. Sebab, agama diperuntukkan bagi akal yang sempurna atau normal. Layaknya orang yang mengalami gangguan jiwa (gila), aqidah beragama anak penyandang autisme tidak dicatat. Walaupun demikian, orang tua memiliki kewajiban untuk tetap memberikan pendidikan agama bagi anaknya yang menyandang autisme. "Orang tua tetap harus maksimal di dalam mendidik anak serta berdo'a, sebba takdir dapat diubah hanya dengan do'a". Hal ini berhubungan erat dengan tipologi anak bagi orang tua yang terbagi menjadi 4 (empat), yakni :1) Perhiasan, 2) Ujian, 3) Musuh, baik musuh fisik maupun musuh biologi, 4) Anak yang qurrota ayyun (enak dipandang). Berkaitan dengan pentingnya pendidikan agama Islam yang diberikan kepada anak penyandang autisme, mengacu pada Al Qur'an Surat Luqman, ada 4 (empat) hal yang orang tua 
harus ajarkan kepada anak, yaitu: 1). Aqidah, 2). Ibadah, 3). Akhlak, 4). Dakwah.

\section{Pemerintah}

Pemerintah telah berupaya di dalam mengelola pendidikan bagi anak-anak berkebutuhan khusus, termasuk di dalamnya anak autisme. Upaya yang dilakukan ini tergambar jelas di dalam peraturan-peraturan yang diberlakukan. Peraturan-peraturan tersebut, antara lain:

a. Undang - Undang Republik Indonesia Nomor 20 tahun 2003 Tentang Sistem Pendidikan Nasional

b. Peraturan Menteri Pendidikan Nasional Republik Indonesia Nomor 70 Tahun 2009 Tentang Pendidikan inklusif bagi Peserta Didik yang memiliki Kelainan dan memiliki Potensi Kecerdasan dan atau Bakat Istimewa

c. Peraturan Menteri Negara Pemberdayaan Perempuan dan Perlindungan Anak Republik Indonesia Nomor 10 tahun 2011 Tentang Kebijakan Penanganan Anak Berkebutuhan Khusus Republik Indonesia

d. Undang-undang Republik Indonesia Nomor 8 tahun 2016 tentang Penyandang Disabilitas

Peraturan-peraturan tersebut disebarkan kepada masyarakat melalui pemerintah daerah atau pemerintah kota yang dibantu oleh dinasdinas pemerintahan. Selama proses penelitian berlangsung, peneliti menemukan ada 3 (dua) dinas yang berkaitan di dalam pengembangan pendidikan penyandang autisme, yaitu 1). Dinas Pendidikan dan Olahraga Kota Palangkaraya, 2).Kementrian Agama Kota Palangka Raya, dan 3).Dinas Sosial dan Transmigrasi Kota Palangkaraya.

\section{KESIMPULAN}

Satu hal yang paling efektif di dalam mengajarkan penyandang autisme agama Islam, yaitu dengan memberikannya "bimbingan". Bimbingan tersebut diberikan baik oleh orang tua, keluarga, guru, teman-teman, masyarakat maupun pemerintah dengan caranya masing-masing. Kondisi ini sangat mendukung tumbuh kembang penyandang autisme.

Bimbingan ini terus-menerus diberikan sejak penyandang autisme masih kecil sampai dewasa, khususnya oleh orang tua dan guru di sekolah. Secara perlahan dan bertahap orang tua dan guru membimbing dengan cara menuntun anak di dalam mempelajari agama Islam. Untuk dapat mempermudah dalam mempelajari agama Islam, penyandang autisme dikenalkan dengan temanteman sebayanya. Teman-teman sebaya ini diberikan pemahaman mengenai kondisi anak autisme. Melalui pemberian pemahaman ini, secara perlahan teman-teman sebaya anak autisme menerima kondisi anak autisme dan mau bersahabat dekat dengannya. Melalui pemahaman yang diberikan guru tersebut, teman-teman sebaya menjadi tidak takut maupun canggung berada di dekat anak autisme. Secara perlahan, mereka menjadi terbiasa dengan perilaku maupun cara anak autisme berinteraksi dan berkomunikasi dengan orang lain. Bahkan, mereka menjadi teman akrab. Teman sebaya atau peserta didik yang lain ini dengan suka rela turut membimbing dengan menuntun anak autisme di dalam mengurus dirinya sendiri.

Tidak hanya dukungan yang diberikan teman sebaya saja, namun dukungan keluarga juga berperan penting bagi anak untuk memahami serta mengamalkan ajaran agama yang sudah diberikan 
kepadanya. Orang tua juga melakukan hal yang sama dengan guru. Mereka memberikan penjelasan kepada saudara kandung anak autisme (bila ada) dan juga kepada keluarganya. Dengan demikian, tidak hanya orang tua yang berperan. Tetapi juga keluarga.

Dalam tugas dan kewajibannya memberikan pendidikan agama Islam pada anak autis, orang tua membimbing dengan berusaha untuk menjadi contoh bagi anak-anaknya. Terutama anaknya yang menyandang autisme. Misalnya dengan mengajak anak untuk sholat dan juga berpuasa, serta mengaji.

Ada beberapa hal yang sangat penting perlu ada di dalam diri orang tua, keluarga, maupun guru dari penyandang autisme di dalam mengajarkan agama Islam, yaitu : adanya keyakinan, ikhtiar, kesabaran, konsistensi, serta ketegasan. Kondisi ini penting, sebab menyesuaikan dengan karakteristik anak autis yang mengalami kesulitan di dalam berinteraksi dan berkomunikasi dengan orang lain serta mengalami kesulitan di dalam persepsinya. Kondisi ini mengakibatkan anak autisme mengalami kesulitan mengurus diri sendiri serta berpartispasi di dalam kegiatan-kegiatan di sekitarnya

Kesulitan-kesulitan yang dialami penyandang autisme ini memberikan kesan bahwa mereka adalah anak yang nakal atau sulit diatur. Untuk itu, anak perlu diajarkan mengenai kepatuhan. $\mathrm{Di}$ dalam mengajarkan anak kepatuhan ini, diperlukan adanya kesabaran, konsistensi, serta ketegasan yang berlandaskan keyakinan kepada Allah SWT. Selain bimbingan, "pemberian perlakuan yang sama" juga menjadi hal yang penting dan tidak bisa diabaikan. Sebab, inilah yang menjadi tujuan orang tua menyekolahkan anaknya yang berkebutuhan khusus di sekolah umum. Adanya keinginan yang kuat di dalam diri orang tua agar anaknya diperlakukan sama dengan anak-anak lainnya. Satu sisi mengakui bahwa anaknya termasuk anak berkebutuhan khusus. Di sisi lain, mereka menganggap bahwa anaknya normal. Anaknya mampu mengikuti pelajaran di sekolah umum dengan baik.Walaupun pada kenyataannya, anak-anak tersebut mengalami kesulitan.

\section{DAFTAR PUSTAKA}

Hasdianah, H.R. 2013. Autis pada anak: Pencegahan, perawatan, dan pengobatan. Yogyakarta : Nuha Medika.

Koswara, D. 2013. Pendidikan Anak Berkebutuhan Khusus : Autis. Jakarta : PT. Luxima Metro Media.

Maghribi, A. 2004. Begini seharusnya mendidikanak: Panduan mendidik anak sejak masa kandungan hingga dewasa. Jakarta : Darul Haq.

Runtukahu, T.J. 2013. Analisis perilaku terapan untuk guru. Jakarta : Ar-Ruzz Media.

Suwaid, M.I.A.H. 2010. Cara Nabi Mendidik Anak. Jakarta: Al l'tishom Cahaya Umat. 